\title{
Breeding of Ethanol-producing and Ethanol-tolerant Saccharomyces cerevisiae using Genome Shuffling
}

\author{
A-Hwang Park ${ }^{1}$ and Yeon-Hee Kim ${ }^{1,2}{ }_{\star}$ \\ ${ }^{1}$ Department of Biomaterial Control, Dong-Eui University, Busan 614-714, Korea \\ ${ }^{2}$ Department of Biotechnology and Bioengineering, Dong-Eui University, Busan 614-714, Korea
}

Received July 18, 2013 /Revised September 3, 2013 /Accepted October 23, 2013

\begin{abstract}
To improve yeast strains for bioethanol production, yeasts with ethanol tolerance, thermotolerance, and $\beta$-1,3-glucanase activity were bred using yeast genome shuffling. Sacharomyces cerevisiae BY4742 $\Delta$ exg1/pAInu-exgA, which has extracellular $\beta$-1,3-glucanase activity, and the Aspergillus oryzae and $S$. cerevisiae YKY020 strains, which exhibit ethanol tolerance and thermotolerance, were fused by yeast protoplast fusion. Following cell fusion, four candidate cells (No. 3, 9, 11, and 12 strains) showing thermotolerance at $40{ }^{\circ} \mathrm{C}$ were selected, and their ethanol tolerance $(7 \%$ ethanol concentration) and $\beta$ 1,3-glucanase activity were subsequently analyzed. All the phenotypes of the two parent cells were simultaneously expressed in one (No. 11) of the four candidate cells, and this strain was called BYK-F11. The BYK-F11 fused cell showed enhanced cell growth, ethanol tolerance, $\beta-1,3$-glucanase activity, and ethanol productivity compared with the BY4742 $\Delta$ exg1/pAInu-exgA and YKY020 strains. The results prove that a new yeast strain with different characters and the same mating type can be easily bred by protoplast fusion of yeasts.
\end{abstract}

Key words : Yeast protoplast fusion, ethanol tolerance, thermotolerance, $\beta$-glucanase, Saccharomyces cerevisiae

\section{서 론}

효모(Saccharomyces cerevisiae)는 오래 전부터 발효 및 양조 산업에 주로 사용되어진 전통 미생물로서, 최근에는 starch나 cellulose와 같은 바이오매스로부터 바이오에탄올의 생산에도 이용되어 지고 있다. 그렇지만 효모는 생산공정 동안의 삼투 압 증가 또는 에탄올 및 이산화탄소의 축적 등과 같은 몇 가지 환경적 변화에도 종종 노출되고 있다[1]. 그 중에서 에탄올은 세계 여러 많은 분야에서 사용되고 있지만 미생물 생장의 주 저해제로 알려져 있기 때문에 배양 중 에탄올의 축적은 세포 성장과 목적 제품의 생산율 감소와 같은 효모 세포에 스트레 스를 준다고 알려져 있다. 따라서 산업적 균주의 에탄올 내성 의 증가는 에탄올을 생산할 수 있는 균주의 육종을 위해서도 반드시 필요한 과정이라고 할 수 있다. 또한 일반적인 효모 균주는 배양 온도 $30^{\circ} \mathrm{C}$ 에서 가장 활발히 자라며 $38^{\circ} \mathrm{C}$ 이상의 온도에서는 성장이 저해되어 온도에도 민감함을 알 수 있다. 하지만 바이오연료 생산과 같이 산업적으로 효모 균주를 이용

\footnotetext{
*Corresponding author

Tel : +82-51-890-2281, Fax : +82-51-890-2632

E-mail : yeonheekim@deu.ac.kr

This is an Open-Access article distributed under the terms of the Creative Commons Attribution Non-Commercial License (http://creativecommons.org/licenses/by-nc/3.0) which permits unrestricted non-commercial use, distribution, and reproduction in any medium, provided the original work is properly cited.
}

하기 위해서는 공정상 생기는 높은 온도에서도 자랄 수 있는 균주가 유용함으로 내열성 균주의 육종도 필요하다고 사료된 다[18].

최근 전 세계적으로 환경문제와 더불어 천연자원의 고갈 문제가 크게 대두되고 있어, 현재 기후변화협약과 환경규제 강화에 의해 친환경 특성을 가지는 에너지 신소재 및 석유를 대체할 수 있는 바이오 연료를 개발하기 위한 연구가 세계적 으로 활발하게 진행되고 있다. 지금까지 바이오에너지의 생산 을 위해 주로 곡물계(starch)와 목질계(cellulose) 바이오매스 를 이용한 바이오 연료 제조 연구가 많이 진행되고 있는 실정 이지만, 유가 상승에 따른 곡물가격의 상승으로 바이오연료 생산을 위한 경제성이 확보되지 않고 있다. 또한 목질계 바이 오매스가 성장하는 장소나 성장기간에 따라 특성이 많이 다르 고 성장 속도가 느린 단점 때문에, 성장 속도가 빠르고 생산량 이 많은 해양 바이오매스(해조류)가 주목을 받고 있다. 하지만 지금까지 에너지 자원으로서 활용도가 낮았던 해조류 바이오 매스를 이용하기 위해서는 해조류 바이오에탄올의 생산성을 높이는 것이 시급한데, 해조다당을 에탄올 생산을 위한 발효 당으로 당화(saccharification)시키는 것이 필요하게 된다. 따 라서 본 연구에서는 해조류 바이오매스 중 갈조류의 저장성 고분자 다당류인 laminaran [12]에 주목하였다. 주로 $\beta-1,3$ linked D-glucose로 되어있는 polymer (glucan)인 laminaran 은 $\beta-1,3$-glucanase 효소에 의해 에탄올 생성을 위한 발효당 glucose로 변환이 가능하며, 생산된 $\beta-1,3$-glucanase는 맥주 생산, 과일의 glucosidic 전구체로부터의 향기로운 화합물 합 
성 및 발효 등을 포함하여 바이오공정공학 프로세스에도 폭넓 게 사용될 수 있다[5, 16, 19]. 그러므로 본 연구에서는 Aspergillus oryzae 유래의 exo- $\beta$-1,3-glucanase인 EXGA 유전 자를 이용하여 laminaran의 당화를 유도하였다[11].

에탄올 내성 및 내열성 향상 등 효모 균주의 특성을 개량하 기 위해서 여러 가지 선택돌연변이, 교배(hybridization), 원형 질체 융합(protoplast fusion), 형질전환(transformation) 등의 방법이 있다. 대부분의 일배체(haploid) 효모들은 a type과 a type의 mating factor를 가지고 있어 쉽게 서로 접합하여 이배 체(diploid) 효모를 형성할 수 있다[9]. 따라서 서로 다른 mating factor를 가진 효모들은 간단히 섞기만 하면 쉽게 hybrid가 가능하다. 실제로 sporulation과 hybridization (mating) 방법 을 이용한 수 차례의 genome shuffling을 통해 향상된 multi-tolerance, 바이오에탄올 생산 및 pentose 발효능이 증가된 효모균주의 육종 등이 보고 되어 지고 있다[2, 24]. 하지만 같은 mating factor를 가진 효모들은 위와 같은 방법으로 hybrid가 불가능함으로 이런 포자형성 또는 hybrid가 안 되는 효모들의 hybrid체를 만들기 위해서 원형질체(protoplast)를 만든 후 융 합하는 genome shuffling 방법을 시도할 수 있다 $[8,9,20]$. 원 형질체 융합(protoplast fusion)은 효모 균주의 세포벽을 제거 하여 원형질체를 만든 뒤 원형질체를 융합시켜 두 개체의 염 색체를 하나의 세포로 도입시킨 fusant를 선별하는 방법이다 [9]. 이는 미생물 균주의 engineering을 위한 획기적인 전략으 로써 유전적 다양성은 원형질체 융합에 의해 이루어질 수 있 다(Fig. 1). 따라서 원형질체 융합에 의한 genome shuffling은 원핵세포와 진핵세포에 모두 적용 가능하여 실제로 성공적인 융합이 보고되어 지고 있다 $[4,7,15,22]$. 또한 genome shuffling은 단순한 균주 간의 융합뿐 만 아니라 DNA shuffling 을 통한 recombination을 유도하기도 하여 완전히 새로운 균 주의 육종도 가능하게 하며, 반복적 multiparental protoplast

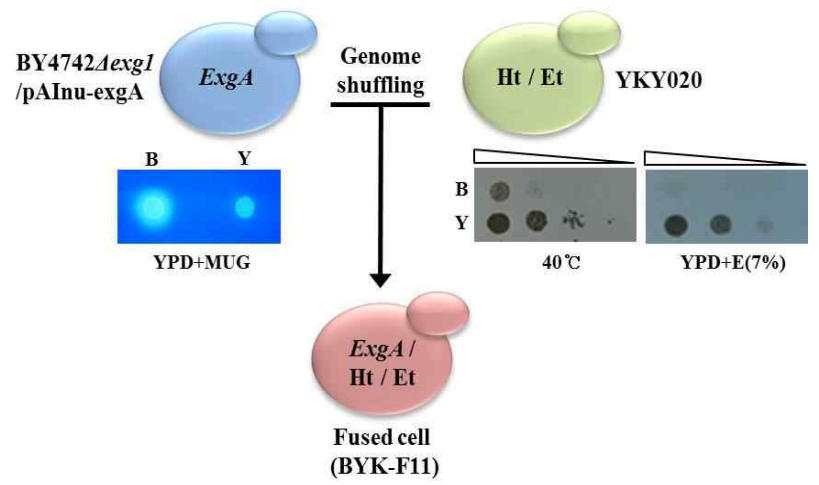

Fig. 1. Construction of novel industrial yeast strain by genome shuffling. Saccharomyces cerevisiae BY4742 4 exg1/pAInuexgA strain and YKY020 strain were fused by yeast protoplast fusion. B, BY4742 Lexg1/ pAInu-exgA strain; Y, YKY020 strain, ExgA: exo- $\beta-1,3-$ glucanase gene, Et: ethanol tolerance, $\mathrm{Ht}$ : heat tolerance. fusion [23]도 가능하게 한다. 하지만 대부분의 genome shuffling법은 야생 균주(wild type strain)를 이용한 protoplast의 $\mathrm{UV}$ 처리 및 mutagen에 의한 돌연변이의 유도를 동반하는 경 우가 대부분이고[2, 18], 재조합 균주의 융합 및 특정 유전자의 발현 증가를 위한 genome shuffling은 거의 보고된 적이 없다. 따라서 본 연구에서는 원형질체 융합을 통한 genome shuffling 방법을 이용하여 에탄올 내성 및 내열성을 가진 균주와 laminaran 분해 활성을 가지는 재조합 균주로부터 새로운 재 조합 융합 균주의 육종을 시도하였다. 또한 개량된 균주를 이 용하여 해조류 유래의 바이오매스로부터 바이오 에탄올 생산 성을 조사하였다.

\section{재료 및 방법}

\section{효모 균주}

본 연구에 사용한 효모 균주는 에탄올 내성과 내열성이 뛰 어난 Saccharomyces cerevisiae YKY020 (MATa leu2-3 40 his3-4 200, $\Delta 1$ 균주와 S. cerevisiae BY4742 $\Delta$ exg1 균주에 Aspergillus oryzae 유래의 exo- $\beta$-1,3-glucanase 유전자 $E X G A)$ 가 도입되어 $\beta$-glucanase 활성을 가지는 BY4742 $\triangle \operatorname{exg} 1 / \mathrm{pAInu}-\operatorname{exgA}(M A T$

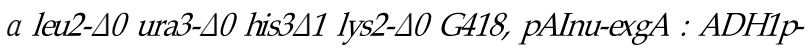
exgA-ADH3t) 균주이다[11].

\section{사용배지 및 배양조건}

효모의 성장배지로는 YPD ( $1 \%$ yeast extract, $2 \%$ peptone, $2 \% \mathrm{dxtrose}$ ) 배지를 사용하였으며, 원형질체 융합을 선별하기 위한 선별배지로는 영양요구성 아미노산(leucine, histidine)이 함유된 SD $(0.67 \%$ yeast nitrogen without base amino acids, $2 \%$ dextrose, $2 \%$ agar) 배지에 원형질체의 삼투압 유지를 위해 $1.2 \mathrm{M}$ sorbitol을 넣은 배지(SD-sorbitol)를 사용하였다. 또한 $\beta$-glucanase의 발현을 위한 배지로는 YPD배지를, 에탄올 내 성을 조사하기 위한 배지는 에탄올이 첨가된 YPD배지를 사용 하였다. 그리고 각각의 효모 균주들의 해조 다당을 이용한 에 탄올 생산을 보기 위해서 $5 \mathrm{ml}$ YPD 배지에서 16 24시간 동안 전배양 한 후, $1 \%$ laminaran (Sigma, UK)이 함유된 YPD ( $1 \%$ dextrose) 배지 $50 \mathrm{ml}$ 에 접종(initial $\mathrm{OD}_{600} 0.1$ )하여 $30^{\circ} \mathrm{C}, 190$ $\mathrm{rpm}$ 에서 48 시간 동안 배양하였다. 또한 내열성 조사를 위해서 효모 균주는 $40^{\circ} \mathrm{C}$ 온도에서 배양되었다.

\section{Zymolase 처리조건}

Genome shuffling을 하기에 앞서 효모 균주들을 원형질체 상태로 만들기 위해 zymolase 처리 조건을 조사하였다. 사용 한 zymolase는 20,600 units/g (Bioshop)을 사용하였으며, 3 $\mathrm{mg} / \mathrm{ml}$ 의 농도로 반응시간 0 분, 10 분, 20 분, 30 분, 40 분, 50 분, 60 분, 90 분, 120 분 동안 처리하였다. 매 시간마다 원형질체 sample을 취하여 현미경을 통해 원형질체 형성 유무를 관찰하 
였다.

\section{원형질체 형성 및 genome shuffling}

S. cerevisiae YKY020과 BY4742 $\triangle$ exg1/pAInu-exgA 균주를 각각 $\mathrm{YPD}$ 배지에 접종하여 $30^{\circ} \mathrm{C}$ 에서 하루 동안 배양하여 자 란 균체 (약 $\left.2 \times 10^{8} \mathrm{cells}\right)$ 를 원심분리하여 회수하였다. 균체는 증류수를 이용하여 세척 한 뒤에 $1.2 \mathrm{M}$ sorbitol과 $0.01 \mathrm{M}$ EDTA가 첨가된 $0.1 \mathrm{M}$ sodium citrate buffer (citrate-sorbitol-EDTA buffer)를 이용하여 다시 세척하고, $0.3 \mathrm{mg} / \mathrm{ml} \mathrm{zy-}$ molase 20T가 첨가된 citrate-sorbitol-EDTA buffer에 현탁하 여 $30^{\circ} \mathrm{C}$ 에서 반응하였다. 그 후 원심분리하여 회수된 균체는 $10 \mathrm{mM}$ calcium chloride를 함유한 $1.2 \mathrm{M}$ sorbitol 용액으로 세척 후 재현탁했다. 이렇게 만들어진 각각의 원형질체를 섞 어 $25^{\circ} \mathrm{C}$ 에서 15 분간 반응한 뒤, $10 \mathrm{mM}$ calcium chloride와 $20 \% \mathrm{PEG}$ 가 첨가된 $1.2 \mathrm{M}$ sorbitol 용액을 첨가 후 $25^{\circ} \mathrm{C}$ 에서 더 반응시켰다. 원형질 융합이 일어난 원형질체를 $1.2 \mathrm{M} \mathrm{sorbi-}$ tol이 첨가된 YPD 액체배지에 재현탁하여 $30^{\circ} \mathrm{C}$ 에서 20 분간 반응시킨 후, 선별배지에 현탁액(약 $6 \times 10^{6}$ cells)을 분주하고 top agar를 부어준 후에 $30^{\circ} \mathrm{C}$ 에서 3 일 정도 배양하였다[6].

\section{융합체(fusant)의 선별}

선별배지에서 자란 colony를 선별하여, hybrid된 균주 (fusant)가 두 모균주, YKY020과 BY4742 4 exg1/pAInu-exgA 의 특성을 모두 가지는지 비교 조사하였다. Fusant의 에탄올 내성 확인을 위해 $7 \%$ 또는 $8 \%$ 에탄올이 포함된 YPD 고체배 지를 사용하여 $30^{\circ} \mathrm{C}$ 에서 3 일 동안 배양하였으며, 내열성 확인 을 위해서는 YPD 고체배지를 사용하여 $40^{\circ} \mathrm{C}$ 에서 2일 동안 배양하여 확인하였다. 모든 균은 액체배지에서 배양한 다음 세포농도 $\left(\mathrm{OD}_{600}\right)$ 를 1 로 맞추고 10 배씩 희석하여 모두 동일한 농도로 spot하여 그 성장 정도를 비교 관찰하였다. 융합체의 $\beta$-glucanase 활성을 보기 위해서 YPD 고체배지를 사용하여 plate assay를 수행하였다. $30^{\circ} \mathrm{C}$ 에서 하루 동안 배양 후, 기질 인 0.04\% MUG (4-methylumbelliferyl-3-D-glucoside) (Fluka Analytical, USA) 용액 $1 \mathrm{ml}$ 을 스프레이하여 $37^{\circ} \mathrm{C}$ 에서 10 분 동안 반응 후 $\mathrm{UV}$ 상에서 형광을 확인하였다 $[10,11,21]$.

Pulse field gel electrophoresis (PFGE)를 통한 핵형 (karyotype) 분석

S. cerevisiae $\mathrm{YKY} 020$ 과 BY4742 $\operatorname{exg} 1 / \mathrm{pAInu}$-exgA 균주의 chromosomal DNA는 Sheehan and Weiss [17]에서 사용된 방법으로 $1 \%$ low melting agarose (Sigma)를 사용하여 DNA plug를 만들어 준비하였다. Chromosomal DNA는 CHEFDRIII system (Bio-Rad Laboratories)를 사용하여 0.5x TBE buffer에 1\% gold agarose (pulsed field certified agarose; Bio-Rad Laboratories, Richmond, CA, USA)를 녹인 겔에서 분리하였다. CHEF gel electrophoresis의 조건은 $120^{\circ}$ 의 angle
로 $6.0 \mathrm{~V} / \mathrm{cm}$ 에서 15시간 동안 60 초의 interval로 switching 후, $6.0 \mathrm{~V} / \mathrm{cm}$ 에서 9시간 동안 90초의 interval로 switching하 였다. 전기영동 후 $0.5 \mu \mathrm{g} / \mathrm{ml}$ 의 ethidium bromide $(\mathrm{EtBr})$ 로 염색 후 UV상에서 karyotype을 확인하였다.

\section{환원당 분석 및 $\beta$-glucanase 효소 활성 측정}

액체 배양 후 배지 중에 남아 있는 환원당을 확인하기 위해 서 DNS (3,5-dinitrosalicylic acid)법을 실시하였다 $[3,14]$. 배양 액을 $13,000 \mathrm{rpm}$ 으로 1 분간 원심분리 후 상등액과 pellet을 분리하여 상등액을 가지고 배지 중에 남아 있는 잔존환원당을 측정하였다. 배양상등액에 DNS 용액 $(1.6 \% \mathrm{NaOH}, 30 \% \mathrm{~K}$ $\mathrm{Na} \cdot$ Tartrate $4 \mathrm{H}_{2} \mathrm{O}, 0.5 \%$ DNS)을 첨가하여 3분 동안 boiling 후 5 분 동안 cooling 시킨 뒤 $550 \mathrm{~nm}$ 에서 흡광도를 측정하여 잔존환원당을 확인하였고, $\beta$-glucanase 효소 활성 측정을 위 해서는 $1 \%$ laminaran을 기질로 하여 $40^{\circ} \mathrm{C}$ 에서 10 분간 반응 시킨 후 DNS법에 의해 활성을 측정하였다. 이때 효소의 활성 은 $1 \%$ laminaran을 이용하여 $40^{\circ} \mathrm{C}$ 에서 1 분당 $1 \mu$ mole의 glucose를 생산하는 효소의 양을 1 unit로 정의하였으며 표준적정 곡선으로 $0.2 \%$ glucose를 사용하였다.

\section{Gas chromatography}

해조 다당을 이용한 에탄올 생산성을 확인하기 위해 배양된 시료를 원심분리 후 상등액을 gas chromatograph (GC)를 이 용하여 분석하였다. GC는 HP 5890 series II 를 사용하였고, 컬럼은 HP-FFAP capillary column (Agilent technologies, Canada, Cross-Linked PEG-TPA 30 m/ 0.25 mm/ $0.25 \mu \mathrm{l}$ )을 사용하였다. 이동상은 $\mathrm{N}_{2}$ 를 $0.6 \mathrm{ml} / \mathrm{min}$ 유속으로 사용하였으 며, 주입구 온도 $150^{\circ} \mathrm{C}$, 검출기 온도 $200^{\circ} \mathrm{C}$, 승온 조건은 $50^{\circ} \mathrm{C}$ $(1.4 \mathrm{~min}) /\left(10^{\circ} \mathrm{C} / \mathrm{min}\right) / 60^{\circ} \mathrm{C}(1 \mathrm{~min}) /\left(25^{\circ} \mathrm{C} / \mathrm{min}\right) / 100^{\circ} \mathrm{C}(1$ $\mathrm{min}) /\left(50^{\circ} \mathrm{C} / \mathrm{min}\right) / 150^{\circ} \mathrm{C}(1 \mathrm{~min})$ 이었다. 분리비는 $70: 1$ 로 했 으며 내부 표준물질로 $1 \%(\mathrm{v} / \mathrm{v})$ 의 isopropanol을 이용하였다. 각각의 실험은 3 번의 independent 실험을 수행하였으며 그 평균값을 산출하였다.

\section{결과 및 고찰}

\section{Genome shuffling에 의한 효모 균주의 융합}

해조류 바이오매스로부터 바이오에탄올을 효율적으로 생 산하기 위한 균주의 육종을 위해 genome shuffling법을 이용 하여 S. cerevisiae BY4742 $\triangle \mathrm{exg} 1 / \mathrm{pAInu}-\mathrm{exgA}$ 균주와 YKY020 균주의 융합을 시도하였다. BY4742 4 exg1/pAInu-exgA 균주 는 해조다당인 laminaran을 잘 분해할 수 있도록 A oryzae의 $\beta$-glucanase가 재조합된 균주로 해조다당으로 부터 바이오에 탄올을 생산하기 위해 해조다당을 발효당으로 당화하는데 필 요한 균주이다. 또한 YKY020 균주는 BY47424exg1/pAInu$\operatorname{exgA}$ 균주와 달리 $40^{\circ} \mathrm{C}$ 에서 내열성을 보이고, $7 \%$ 의 에탄올 
농도에서도 잘 자라는 에탄올 내성을 가지는 균주이다(Fig. 1). 이 두 균주를 zymolase를 사용하여 원형질체화하였는데, 효소처리 60 분까지는 원형질체가 관찰되지 않았으며, 90 분이 경과되었을 때 부터 균체의 약 $40 \%$ 이상의 원형질체가 확인이 됨을 알 수 있었다(data not shown). Zymolase 처리 120분 후, 각각의 원형질체를 융합시키고 leucine과 histidine이 첨가 된 SD 선별배지에서 배양 후, 자란 37개의 colony 중 growth 가 좋은 hybrid 균주 13 개를 1 차 선별하였다. 선별된 균주를 YPD배지로 옮기고 hybrid 의 유무를 알아보기 위해 내열성, 에탄올 내성 및 $\beta$-glucanase의 활성을 조사해 보았다

\section{융합 효모 균주의 내열성 조사}

선별된 13 개의 균주들을 2 차 선별하기 위해 우선 $40^{\circ} \mathrm{C}$ 에서 내열성을 조사 해 본 결과, 4 개의 균주(No. $3,9,11,12$ )에서 내열성이 확인되었다. 그리고 내열성을 조금 보였던 2 개의 균 주(No. 10과 13)도 추가적으로 선별하였다. 6개의 균주를 동일 한 농도로 spot하여 $40^{\circ} \mathrm{C}$ 에서 2일 동안 배양한 결과, 모균주인 YKY020 균주는 내열성이 있어 $40^{\circ} \mathrm{C}$ 에서 자라는 것을 확인하 였지만, 또 다른 모균주인 BY4742 $\Delta$ exg1/pAInu-exgA 균주는 내열성이 없어 배양 온도 $40^{\circ} \mathrm{C}$ 에서는 거의 자라지 못함을 알 수 있다. 4 개의 균주(No. 3, 9, 11, 12)에서는 모균주인 YKY020 균주와 비슷한 정도의 내열성을 보임을 확인 할 수 있었다 (Fig. 2A).

\section{융합 효모 균주의 에탄올 내성 조사}

2차로 선별된 6 개의 균주를 대상으로 에탄올 내성을 확인해 보았다. $7 \%$ 에탄올이 첨가된 YPD 고체배지에 각각의 균주를 동일한 농도로 spot 하여 $30^{\circ} \mathrm{C}$ 에서 3 일 동안 배양하였다. 그 결과 모균주인 YKY020은 에탄올에 내성이 있어 YPDE $(7 \%)$ 배지에서 잘 자라는 것을 확인하였지만, 또 다른 모균주인 BY4742 4 exg1/pAInu-exgA는 YKY020 균주보다 에탄올 내성 이 낮아 YPDE (7\%) 배지에서 잘 자라지 못하는 것을 확인하였 다. 6 개의 균주 중 내열성을 보이는 4 개의 균주(No. $3,9,11$, 12)에서 마찬가지로 에탄올 내성을 나타냄을 확인 할 수 있었
고 그 중에서 No. 3 과 11 균주가 에탄올 내성이 뛰어남을 알 수 있었다(Fig. 2B).

\section{융합 효모 균주의 $\beta$-glucanase 활성 조사}

내열성과 에탄올 내성이 있는 4 개의 균주의 경우 원형질 융합체가 아닌 모균주인 YKY020 균주일 가능성도 배제 할 수 없다. 따라서 다른 모균주의 특성인 $\beta$-glucanase의 활성이 있는지를 plate 활성법을 이용하여 조사하였다. YPD배지에 각각의 균주를 동일한 농도로 spot하여 $30^{\circ} \mathrm{C}$ 에서 1 일 배양하 고, $0.04 \% \mathrm{MUG}$ 용액을 분주 한 후 UV 램프 위에서 $\beta$-glucanase활성을 비교하였다. YKY020 모균주에서는 원래 효모에 존재하는 $\beta$-glucanase 유전자 $(E X G 1)$ 에 의한 약한 형광이 관 찰되었다. 반면에 BY4742 $\operatorname{exg} 1 / \mathrm{pAInu}-\mathrm{exgA}$ 균주는 원래 BY4742 균주 내에 존재하는 EXG1유전자를 결실(exg1)시키고 EXG1유전자보다 활성이 더 높은 A. oryzae 유래의 B-glucanase 유전자인 $E X G A$ 유전자를 재조합 시킨 균주로 활성 염색 에 의해 균 주변까지 넓은 범위의 형광이 관찰됨을 확인 할 수 있었다. 선별된 6개의 균을 조사해 본 결과, No. 11 과 13 균주에서 BY4742 4 exg1/pAInu-exgA 균주 정도의 활성을 보 임을 알 수 있었다(Fig. 2C). 따라서 No.11 균주가 내열성, 에탄 올 내성 및 $\beta$-glucanase의 활성을 동시에 가지는 융합 균주임 을 확인하였으며, 이 균주를 S. cerevisiae BYK-F11 (MATa leu2-3 $\Delta 0$ ura3- $\Delta O$ his3- $\Delta 200, \Delta 1$ lys2- $\Delta O$ G418, pAInu-exgA)이 라고 명명하였다.

\section{BYK-F11 균주의 특성 및 karyotype 조사}

Genome shuffling이 일어난 BYK-F11균주의 경우, 모균주 가 가지는 $\beta$-glucanase 활성 뿐만 아니라 내열성, 에탄올 내성 도 증가되었을 가능성이 크다. 이는 일배체의 균주보다 이배 체의 균주에서 보여지는 성장속도의 증가 및 대사산물 생산율 향상 등과도 연관이 있을 수 있다. 따라서 모균주 및 BYK-F11 균주의 $\beta$-glucanase의 활성을 정량 분석해보았다. 각각의 균 주를 YPD배지에서 24시간 동안 배양한 후, $\beta$-glucanase 활성 을 조사해 본 결과, BY4742 $\Delta \mathrm{exg} 1 / \mathrm{pAInu}$-exgA 균주에서 4.3
A

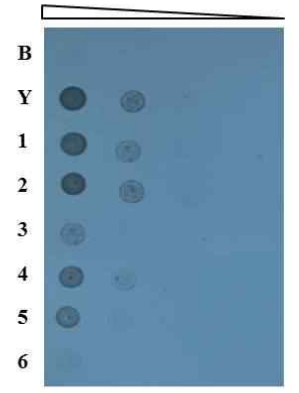

$40^{\circ} \mathrm{C}$
B

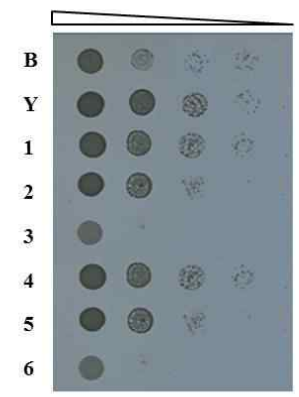

YPD+E (7\%)
C

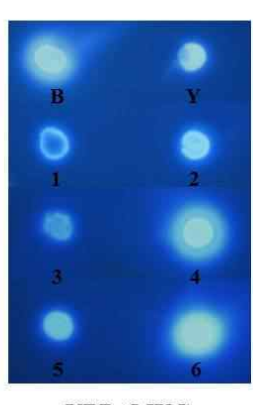

Fig. 2. Screening of yeast fused cells having thermostability, ethanol tolerance and/or $\beta$-glucanase activity. (A) Aliquots $(3 \mu \mathrm{l})$ of 10 -fold serially diluted cell suspensions from $S$. cerevisiae BY4742 4 exg1/ pAInu-exgA, YKY020 and yeast fused cells were spotted on to YPD, then incubated for 2 days at $40^{\circ} \mathrm{C}$. (B) Aliquots were spotted on to YPD containing 7\% ethanol (YPDE) and incubated for 3 days at $30^{\circ} \mathrm{C}$. (C) Aliquots were spotted on to YPD and $\beta$-glucanase activity was detected by MUG degradation on UV illumination. B, BY4742 Aexg1/ pAInu-exgA strain; $Y$, YKY020 strain; 1 , fused cell No. 3; 2, fused cell No. 9; 3, fused cell No. 10; 4, fused cell No. 11; 5, fused cell No. 12; 6, fused cell No. 13. 
A

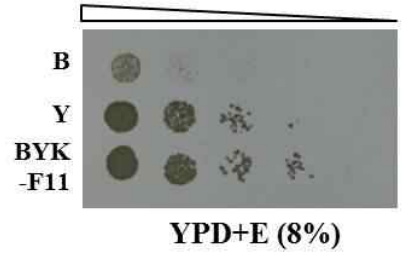

B

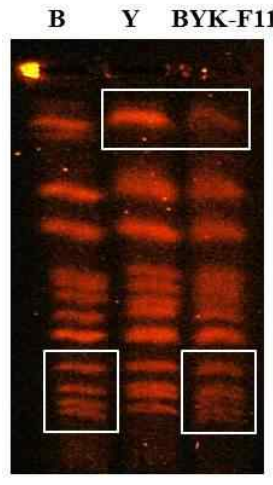

PFGE

Fig. 3. Analysis for ethanol tolerance and karyotype of BYK-F11 fusant. (A) Aliquots ( $3 \mu \mathrm{l}$ ) of 10-fold serially diluted cell suspensions from BY4742 Jexg1/ pAInu-exgA, YKY020 strain and BYK-F11 fusant were spotted on to YPD containing $8 \%$ ethanol (YPDE), then incubated for 3 days at $30^{\circ} \mathrm{C}$. (B) Karyotype analysis of $S$. cerevisiae BY4742 $\triangle$ exg1/pAInu-exgA, YKY020 strain and BYK-F11 fusant by CHEF gel electrophoresis. Lane B: BY4742 Lexg1/pAInuexgA strain, lane Y: YKY020 strain.

unit/ml이었던 효소활성이 BYK-F11 균주에서는 4.92 unit/ $\mathrm{ml}$ 로 약 $15 \%$ 정도 활성이 증가되었음을 확인하였다. 또한 $8 \%$ 에탄올 배지에서 에탄올 내성을 비교해 본 결과, BYK-F11균주 에서 에탄올 내성이 조금 증가된 것을 확인할 수 있었다(Fig. $3 \mathrm{~A})$. 다음으로 PFGE 분석을 통해 각 균주들의 karyotype을 분석 해 본 결과, BYK-F11 균주에서 두 모균주의 karyotype이 혼합된 형태를 보였고, 원형질 융합에 의해 두 genome이 잘 융합되었음을 확인 할 수 있었다(Fig. 3B).

\section{$\mathrm{BYK}-\mathrm{F} 11$ 균주의 에탄올 생산성 조사}

YKY020 균주와 BY4742 $\Delta$ exg1/pAInu-exgA 균주 및 fusant 인 BYK-F11 균주를 YPD ( $1 \%$ dextrose) 에 $1 \%$ 의 laminaran이 함유된 배지로 $30^{\circ} \mathrm{C}$ 에서 48 시간 동안 진탕배양하여 성장속도, 잔존환원당 및 에탄올 생산성을 측정하였다. 일배체인 다른 모균주와 비교해서 이배체인 BYK-F11 균주는 성장속도에서 부터 모균주와 비교하여 약 2배의 차이를 보였다(Table 1). 또 한 배양 24 시간째에는 배지 중에 존재하던 $10 \mathrm{~g} / 1$ 의 dextrose

및 laminaran으로 부터의 단당도 거의 다 소모하여 $0.5 \mathrm{~g} / 1$ 만 남아있음을 확인하였다. 배양 24 시간째에 배양 상등액에 존재 하는 에탄올의 농도는 $6.8 \mathrm{~g} / 1$ 정도이었으며 glucose와 laminaran으로 부터의 에탄올 수율은 $0.34 \mathrm{~g} / \mathrm{g}$ 이었다(Table 1). 이는 모균주인 BY4742 4 exg1/pAInu-exgA 균주보다 $6.3 \%$ 정 도의 에탄올 수율 증가를 의미하며, sporulation과 mating을 통한 genome shuffling으로 $3.11 \%$ 의 에탄올 수율 증가를 보인 결과[24]와 비교해 약 2 배 정도 증가된 값임을 알 수 있었다. 또한 YKY020 균주는 laminaran 분해능이 떨어짐으로 첨가한 glucose에 의한 에탄올 생산만이 가능하여 상대적으로 laminaran으로부터 에탄올 수율이 낮음을 알 수 있다. 최근에는 배양 온도의 증가에 따른 에탄올 생산율의 증가도 보고되어있 어[13], BYK-F11균주에 대해 $40^{\circ} \mathrm{C}$ 의 배양온도에서의 에탄올 생산성을 조사해보았다. YPD ( $1 \%$ dextrose)에 $1 \%$ 의 laminar$\mathrm{an}$ 이 함유된 배지에서 48 시간 동안 $40^{\circ} \mathrm{C}$ 에서 진탕 배양하여 성장속도 및 에탄올 생산성을 측정한 결과, $30^{\circ} \mathrm{C}$ 에서 배양했 을 때보다 성장속도는 약 $23 \%$ 정도 감소하였지만 에탄올 수율 은 $0.33 \mathrm{~g} / \mathrm{g}$ 로 $30^{\circ} \mathrm{C}$ 에서와 비교하여 큰 차이를 보이지 않았다 (Table 1). 이는 세포의 성장이 멈추더라도 어느 정도는 에탄올 을 생산 할 수 있음을 시사한다. 하지만 Lin et. al의 보고[13]에 서처럼 specific ethanol production rate (g-ethanol/ kg-cell $\mathrm{mass} / \mathrm{h}$ 로 환산하면, $30^{\circ} \mathrm{C}$ 에서 배양한 것 보다 약 $25 \%$ 의 에탄 올 수율이 향상되었다고 할 수 있다. 따라서 본 연구에서는 재조합 균주를 genome shuffling 법을 통해 새로운 형질을 가 진 재조합 균주로 육종 할 수 있음을 확인하였고, 목적에 따른 반복적인 융합에 의해 산업적 이용가치가 높은 균주 및 특정 유전자 발현 cassette를 가진 균주의 개량에도 응용 가능할 것 이라 기대된다.

\section{감사의 글}

본 연구는 2012학년도 동의대학교 일반 연구과제(과제번 호; 2012AA194) 지원에 의하여 이루어졌으며, 이 연구에 참여 한 박아황은 교육부의 2 단계 BK21 사업의 지원을 받았습니다. 연구비 지원에 감사드립니다.

Table 1. Comparison of cell growth, reducing sugar, ethanol yield and specific growth rate ( $\mu)$ in each strain

\begin{tabular}{|c|c|c|c|c|c|c|c|}
\hline \multirow{2}{*}{ Strains } & \multicolumn{2}{|c|}{ Cell growth $\left(\mathrm{OD}_{600}\right)$} & \multicolumn{2}{|c|}{ Reducing sugar $(\mathrm{g} / \mathrm{l})$} & \multicolumn{2}{|c|}{$\begin{array}{c}\text { Ethanol yield } \\
(\mathrm{g} / \mathrm{g} \text {-carbon source })^{\mathrm{a}}\end{array}$} & \multirow{2}{*}{$\mu_{\max }(\mu)$} \\
\hline & $24 \mathrm{hr}$ & $48 \mathrm{hr}$ & $24 \mathrm{hr}$ & $48 \mathrm{hr}$ & $24 \mathrm{hr}$ & $48 \mathrm{hr}$ & \\
\hline BY4742_exg1 / pAInu-exgA & 12.87 & 15.03 & 0.51 & 0.49 & 0.32 & 0.26 & $0.65(0.33)$ \\
\hline YKY020 & 13.72 & 14.69 & 0.76 & 0.63 & 0.18 & 0.24 & $0.69(0.37)$ \\
\hline BYK-F11 & 21.16 & 22.33 & 0.54 & 0.51 & 0.34 & 0.30 & $0.85(0.37)$ \\
\hline BYK-F11 $\left(40^{\circ} \mathrm{C}\right)$ & 16.26 & 17.51 & 0.69 & 0.61 & 0.33 & 0.31 & $0.71(0.36)$ \\
\hline
\end{tabular}

ag-carbon source means the amount of consumed glucose and laminaran. 


\section{References}

1. Attfield, P. V. 1997. Stress tolerance: the key to effective strains of industrial baker's yeast. Nat Biotechnol 15, 1351-1357.

2. Bajwa, P. K., Pinel, D., Martin, V. J., Trevors, J. T. and Lee, H. 2010. Strain improvement of the pentose-fermenting yeast Pichia stipitis by genome shuffling. J Microbiol Methods 81, 179-186.

3. Bara, M. T. F., Lima, A. L. and Ulhoa, C. J. 2003. Purification and characterization of an exo- $\beta$-1,3-glucanase produced by Trichoderma asperellum FEMS Microbiol Lett 219, 81-85.

4. Dai, M. H. and Copley, S. D. 2004. Genome shuffling improves degradation of the anthropogenic pesticide pentachlorophenol by Sphingobium chlorophenolicum ATCC 39723. Appl Environ Microbiol 70, 2391-2397.

5. Guegen, Y., Chemardin, P., Janbon, G., Arnaud, A. and Galzy, P. 1996. A very efficient $\beta$-glucosidase catalyst for the hydrolysis of flavor precursors of wines and fruit juices. J Agric Food Chem 44, 2336-2340.

6. Harashima, S., Takagi, A. and Oshima, Y. 1984. Transformation of protoplasted yeast cells is directly associated with cell fusion. Mol Cell Biol 4, 771-778.

7. Hida, H., Yamada, T. and Yamada, Y. 2007. Genome shuffling of Streptomyces sp. U121 for improved production of hydroxycitric acid. Appl Microbio Biotech 73, 1387-1393.

8. Hou, L. 2010. Improved production of ethanol by novel genome shuffling in Saccharomyces cerevisiae. Appl Biochem Biotechnol 160, 1084-1093.

9. Jeon, H. T., Park, U. M. and Kim, K. 2011. The use of aureobasidin A resistant gene as the dominant selectable marker for the selection of industrial yeast hybrid. Korean $J$ Microbiol Biotechnol 39, 111-118.

10. Jijakli, M. H. and Lepoivre, P. 1998. Characterization of an exo- $\beta-1,3$-glucanase produced by Pichia anomala strain K, antagonist of Botrytiscinerea on apples. Phytopathology 88, 335-343.

11. Kim, M. J., Nam, S. W., Tamano, K., Machida, M., Kim, S. K. and Kim, Y. H. 2011. Optimazation for production of exo-B-1,3-glucanase (laminarase) from Aspergillus oryzae in Saccharomyces cerevisiae. Korean Soc Biotech Bioeng 26, 427-432.

12. Lee, S. M., Kim, J. H., Cho, H. Y., Joo, H. and Lee, J. H. 2009. Production of bio-ethanol from brown algae by phys- icochemical hydrolysis. J Korean Ind Eng Chem 20, 517-521.

13. Lin, Y., Zhang, W., Li, C., Sakakibara, K., Tanaka, S. and Kong, H. 2012. Factors affecting ethanol fermentation using Sacharomyces cerevisiae BY4742. Biomass Bioenergy 47, 395401.

14. Miller, G. L. 1959. Use of dinitrosalicylic acid reagent for the determination of reducing sugar. Anal Chem 31, 426-428.

15. Patnaik, R., Louie, S., Gavrilovic, V., Stemmer, W. P. C., Ryan, C. M. and Cardayre, S. 2002. Genome shuffling of lactobacillus for improved acid tolerance. Nature Biotech 20, 707-712

16. Pitson, S. M., Seviour, R. J. and McDougall, B. M. 1993. Noncellulolytic fungal beta-glucanases: their physiology and regulation. Enzyme Microb Technol 15, 178-192.

17. Sheehan, C. and Weiss, A. S. 1990. Yeast artificial chromosome: rapid extraction for high resolution analysis. Necleic Acids Res 18, 2193.

18. Shi, D. J., Wang, C. L. and Wang, K. M. 2009. Genome shuffling to improve thermotolerance, ethanol tolerance and ethanol productivity of Saccharomyces cerevisiae. J Mircobiol Biotechnol 36, 139-147.

19. Shoseyov, O., Bravdo, A. B., Ikan, R. and Chet, I. 1990. Immobilized endo- $\beta$-glucosidase enriches flavor of wine and passion fruit juice. J Agric Food Chem 27, 1973-1976.

20. Spencer, J. F. T. and Spencer, D. M. 1983. Genetic improvement of industrial yeast. Ann Rev Microbiol 37, 121-142.

21. van Rensburg, P., van Zyl, W. H. and Pretorius, I. S. 1997. Over-expression of the Saccharomyces cerevisiae exo- $\beta$ 1,3-glucanase gene together with the Bacillus subtilis endo- $\beta$ 1,3-1,4-glucanase gene and the Butyrivibrio fibrisolvens endoß-1,4-glucanase gene in yeast. J Biotechnol 55, 43-53.

22. Wei, P., Li, Z., He, P., Lin, Y. and Jiang, N. 2008. Genome shuffling of ethanologenic yeast Candida krusei for improved acetic acid tolerance. Biotech Appl Biochem 49, 113-128.

23. Zhang, Y. X., Perry, K., Vinci, V. A., Powell, K., Stemmer, W. P. and del Cardayré, S. B. 2002. Genome shuffling leads to rapid phenotypic improvement in bacteria. Nature 415, 644-646.

24. Zheng, D. Q., Wu, X. C., Tao, X. L., Wang, P. M., Li, P., Chi, X. Q., Li, Y. D., Yan, Q. F. and Zhao, Y. H. 2011. Screening and construction of Saccharomyces cerevisiae strains with improved multi-tolerance and bioethanol fermentation performance. Bioresour Technol 102, 3020-3027. 
초록 : Genome shuffling을 이용한 에탄올 생산 및 내성 효모 균주의 육종

박아황 ${ }^{1} \cdot$ 김연희 $^{1,2} \star$

('동의대학교 바이오물질제어공학과, ${ }^{2}$ 동의대학교 생명공학과)

바이오 에탄올 생산을 위한 최적 효모균주의 개량을 위해 효모 genome shuffling 법을 이용하여 에탄올내성, 내열성 및 $\beta-1,3$-glucanase 활성을 가진 효모균주의 육종을 계획하였다. 본 연구에서는 세포 외 $\beta-1,3$-glucanase 활성을 가진 Saccharomyces cerevisiae BY4742_exg1/pAInu-exgA 균주와 에탄올내성 및 내열성을 가진 S. cerevisiae YKY020 균주를 효모 protoplast fusion을 통하여 융합시켰다. 세포융합에 의해 $40^{\circ} \mathrm{C}$ 에서 내열성을 보이는 네 개 의 후보 균주(No. 3, 9, 11, 12)를 선별한 다음, $7 \%$ 에탄올 농도에서의 에탄올내성 및 $\beta-1,3$-glucanase 활성을 조사 하였다. 두 모균주의 모든 표현형을 보이는 하나의 균주(No. 11)가 선별되었고, 이 균주를 BYK-F11이라고 명명하 였다. BYK-F11 융합균주는 BY4742_exg1/pAInu-exgA와 YKY020균주에 비해서 증가된 세포성장속도, 에탄올 내 성, $\beta-1,3$-glucanase 활성 및 에탄올 생산성을 보임을 알 수 있었다. 따라서 본 연구에서는 다양한 특성을 가지지만 같은 접합형을 가진 효모균주들을 protoplast fusion법을 사용하여 손쉽게 새로운 산업용 효모균주로 육종시킬 수 있다는 것을 증명하였다. 